\title{
A Phonological and Morphological Sketch of Isanzu Lect (Bantu, Tanzania)
}

\author{
Stanislav Beletskiy* \\ and Mark Paul Diyammi \\ University of Dodoma \\ P.O. Box 259, Dodoma, Tanzania
}

Received 02.12.2018, received in revised form 28.12.2018, accepted 10.01.2019

This paper presents the outcomes of a short linguistic fieldwork on a Bantu lect Isanzu (F31B) that is spoken in the north central Tanzania. Data collection aimed at basic description of phonetics and morphology. Method used to achieve this goal consists of translational elicitation of the 207-item Swadesh list, H. Batibo's questionnaire on Bantu morphosyntax as well as of recrodings and transcriptions of two narratives (a fairy tale and a Pear story). The analyses of data show that Isanzu possesses $7 V$-system /i, e, a, o, o, u/, 24 item consonant inventory $/ p, b, t, d, k, g, m, m, n, n, n, \dot{\eta}, \eta, f, s, \int, x, h, d z, d b, r, l, w, j /$ and 2 level tones $(H, L)$. Isanzu noun class system comprises 15 agreement classes with the following markers [nominal-pronominal]: 1 [mo-o], 2 [a-a], 3 [mo-o], 4 [me-e], 5 [i-la], 5a [lo/ro-lo/ro], 6 [maa], 7 [ke-ke], 9 [N-i,e], 10 [N-zi], 11 [lo-o], 13 [ka-ka], 15 [ko-ko], 16 [pa-pa], 17 [ko-ko], 18 [mo-mo]. Noun prefixes with /o/ are augmented with o, other noun prefixes are augmented with e. Isanzu verb structure includes following slots [morphemes]: negation [sha], subject marker [n, $u, o, k, m$, ale, nominal markers], tense-aspect-mood marker 1 [e 'present', a 'past', ka 'narrative past', o 'future'], extension 1 [( $k) i$ 'reflexive/reciprocal'], object marker [ni, ko, mo, ke, wa, wa, nominal markers], root, extension 2 [i 'applicative', w 'passive', $z$ 'causative', ag 'durative', ek/ik 'stative'], tense-aspect-mood marker 2 [ire 'perfective'], final vowel [a 'indicative', e 'subjunctive / optative / perfective']. Phonetics and morphology of Isanzu reveal its conservative and regular nature. The results of this study may be useful in comparative and historical research of Bantu languages.

Keywords: Isanzu, Bantu, Tanzania, field linguistics, 7 V-system, noun classes.

Research area: philology.

Citation: Beletskiy, S., Diyammi, M.P. (2019). A phonological and morphological sketch of Isanzu lect (Bantu, Tanzania). J. Sib. Fed. Univ. Humanit. soc. sci., 12(1), 4-19. DOI: 10.17516/1997-1370-0376.

(C) Siberian Federal University. All rights reserved

* Corresponding author E-mail address: stas.beletskiy@gmail.com

This work is licensed under a Creative Commons Attribution-NonCommercial 4.0 International License (CC BY-NC 4.0). 


\section{Introduction}

Isanzu (also Ihaanzu, Issansu, Kiisanzu, Kinyihanzu, Kinyisanzu) is a member of the Bantu language family spoken in the north-central part of Tanzania (Singida region, Iramba district). In his New Updated Guthrie List, J.F. Maho situates Isanzu within Nilamba-Rangi group (F30) as one of the dialects of Nilamba language (F31) and labels it F31B (Maho, 2009: 45). However, the speakers of Isanzu - Anyihanzu people - believe they speak the Kiihanzu language. Nevertheless, they admit it is closely related to Nilamba and Nyaturu (F32). Moreover, in the Ethnologue data-base Isanzu is also treated as a separate language (Isanzu: A language of Tanzania, 2018). In this paper Isanzu will be referred as 'lect' ' because of two reasons: 1) lack of research supporting its statues neither as a language nor as a dialect; 2) number of speakers involved as consultants in the research (only one speaker was interviewed hence we describe an idiolect).

The Atlas of Tanzanian languages estimates the number of Isanzu speakers at 26000 (Atlasi ya lugha za Tanzanina, 2009: 67). As it is the case with the majority of ethnical community languages in Tanzania, Isanzu is heavily exposed to the effects of bilingualism of its speakers with Swahili being the dominant language (Legère, 2002; Batibo, 2005; Muzale, Rugemalira, 2008; Petzel, 2012), what along with the relative small number of speakers lowers the vitality index of Isanzu that is currently assessed by the Ethnologue as $6 \mathrm{~b}$ - threatened.

Publications about Anyihanzu people and the language variety they speak are scarce. Mostly they mention Anyihanzu as exceptionally friendly neighbours to a far more intriguing tribe who acquired Isanzu language as a second language, namely Hadza people - the last hunter-gatherer tribe in Africa (Kotlar, 1975: 75). To the best of our knowledge as well as according to the Glottologue data-base there is no single sound linguistic description of Isanzu lect (Isanzu, 2018). The only available resource of information about it is the $\mathrm{PhD}$ thesis (Masele, 2001) that presents quite a huge amount of lexical data from Isanzu lect (a more than 1,000 item list of core and cultural vocabulary) to test the hypothesis of the research - the genetic inconsistence of the zone F with Sisumbwa, Sukuma, and Nyamwezi languages being the main focus of the study.

According to (Masele, 2001) Isanzu exhibits typical for F30 group conservative phonological system ( 7 vowels as opposed to 5 vowels in non-conservative Bantu

\footnotetext{
"Term introduced in American variational sociolinguistics to designate regional, social, and other types of language varieties. In compound words (e.g. sociolect, dialect, idiolect, isolect, etc.), the first element indicates the type of variety" (Bussmann, 2006: 666).
} 
languages and quite old, similar to Proto-Bantu, consonant inventory). Its conservative nature is explained by the fact that F30 languages including Isanzu did not (fully) undergo Bantu spirantization process. However Isanzu is also characterized by some innovations including a set of voiceless nasals.

\section{Statement of the problem}

The majority of at about 400 Bantu languages and their dialects are still poorly described if at all. Many of more than 120 Bantu languages spoken in Tanzania are going to disappear in the nearest future as they "exist in a hostile political environment. $<\ldots>$. They are not permitted in the schools, in the media, or in politics" (Muzale, Rugemalira, 2008: 69). Very often they are neglected by native speakers who abandon them in the favour of the dominant national language Swahili. But at the same time "each human language has a unique linguistic inventory and rules, reflects its own cultural experience, expresses its own world view and manifests its own artistic peculiarities. Thus, taken together, all the more than 2000 African languages have an enormous wealth of linguistic, cultural, world view and artistic phenomena to offer to humankind" (Batibo, 2005: 43). For a linguist it is imperative if not to prevent this process than to record and study these languages and dialects before they disappear.

Regrettably, Isanzu is one of those vulnerable language varieties. It is considered to be threatened (6b in the Ethnologue's classification) and lacks any sound linguistic description. Because of these two reasons and encouraged by the familiarity with the area where Isanzu is spoken the authors of this paper decided to undertake a field research on Isanzu lect in August 2018. The objective of the research was to document Isanzu lect, in other words to collect phonetic, lexical and textual data of Isanzu for further description. This endeavour found a firm support from the side of the 4 Corners Cultural Programme (4CCP), an NGO situated in the town of Haydom (Manyara region) that supports cultural and language diversity in the area where representatives of all four African language families come into contact.

\section{Theoretical framework}

This study combines two approaches to linguistic fieldwork - documentary and descriptive.

Descriptive linguistic fieldwork can be defined as "the investigation of the structure of a language through the collection of primary language data gathered through interaction with native-speaking consultants" (Chelliah, de Reuse, 2011: 7). It sees the 
main goals of linguistic fieldwork in writing grammars, compiling dictionaries and publishing collections of texts.

Documentary linguistic fieldwork can be defined as "a lasting, multipurpose record of a language" (Himmelman, 2006: 1). This approach puts a strong emphasis on recording (audio, video) of linguistic observable behaviour. Structural analyses of collected data might not be an objective of a documentary project at all. It aims at gathering and archiving data to make it accessible to a broader scientific community and future generations of native speakers who might be interested in revitalization of their ancestors' language.

According to the objectives of this study we applied descriptive approach enriched with documentary "ideology". We believe that a first description of a previously unresearched language cannot be reduced to a mere documentation. A linguist should elaborate basic understanding of phonetics morphology and syntax prior to documentation as it normally requires transcriptions of audio and video recordings an unrealistic task to accomplish for someone who does not understand systematic relationships within language system. However, methods of descriptive approach do not disallow the procedures of obtaining data to be recorded, archived and disseminated.

\section{Methods}

The fieldwork was conducted between 16-18 August 2018 in the office of 4 Corners Cultural Programme (4CCP) in Haydom (Manyara region) with the male consultant Erasto John Linza (38 years old, farmer, competent speaker).

Within the descriptive approach we applied the following methods of data collection: translational elicitation ${ }^{1}$ (to obtain basic vocabulary, morphological and syntactic patterns) and text collection (to obtain narratives).

For translational elicitation the researchers used two techniques: wordlist and questionnaire. During translational wordlist elicitation the consultant is asked to translate a number of words into his/her mother tongue from another language that is intelligible to him/her and researcher. The study used the 207-item Swadesh list. The explorers believe the obtained results will be of interest for linguists working on lexicostatistics, glottochronology and dialectology of Bantu languages (especially of zone F).

"Elicitation means collecting linguistic data by asking native speakers to produce words, phrases, or sentences that can serve as data for the analyses of a particular linguistic phenomena" (Mosel, 2012: 79). 
For eliciting morphological and syntactic patterns of Isanzu lect, the researchers used Questionnaire on morphological characteristics in Bantu languages (Batibo, 1990 in Hamisi, 2010: 243-255). It contains 256 sentences in Swahili that test Bantu nominal prefixes, verb forms, and basic sentence structure. The consultant was asked to translate these sentences into his mother tongue.

Further, the consultant was asked to tell the researchers one of his favourite fairy tales and it was recorded and transcribed. After that he was shown the Pear story ${ }^{l}$ and asked to retell the story. The narration was recorded, transcribed and annotated.

All elicitation sessions were recorded with a digital recorder in high quality (WAV) in order to enable researchers to perform a subsequent computerized acoustic analysis using Praat program. Morphological analysis was exercised in SIL Field Work Explorer 8. The same program was used to compile a wordlist, to annotate and archive the data. Interested reader can access the data on the first author's web-page ${ }^{2}$ or request access to it sending an email to the first author.

\section{Discussion}

\section{Vowels}

Isanzu contrasts 7 vowels: two high, four middle (closed and open sets) and one low.

The closed mid vowels are articulate with quite low F1 what makes them be auditory perceived rather as open high vowels. Obviously this auditory interpretation was used for transcription conventions in (Masele, 2001) where the vowel inventory of Isanzu is represented as /i, I, e, a, o, $\mathrm{v}, \mathrm{u} /$. However the F1 and F2 measurements done with Praat (Fig. 1) suggest the following transcription: /i, e, a, o, o, u/. The openness of $/ \varepsilon, \mathrm{o} /$ is clearly visible on the acoustic vowel chart. The mid-close nature of $/ \mathrm{e}, \mathrm{o} / \mathrm{rather}$ than their high-open nature /I, $\mho /$ is supported by the fact that they differ in F2 from the respective high vowels $/ \mathrm{i}, \mathrm{u} /$. In this decision we follow the argumentation used by transcription of mid close vowels in Nyamwezi (F22) (Maddieson, 2003: 17).

All 7 vowels can bear a tone - high (marked as ' above the vowel) or low (unmarked) and be lengthened (disregarding the tone type), for example: kogópa 'to fear' vs. mogəongo 'back [body part]'. Our data was not sufficient to make any generalisations about nature and functions of tone.

A short video used as a stimulus in fieldwork (available at: http://pearstories.org).

Available at: http://ifiyak.sfu-kras.ru/beleckiy-stanislav-borisovich-nauchnye-proekty/ 


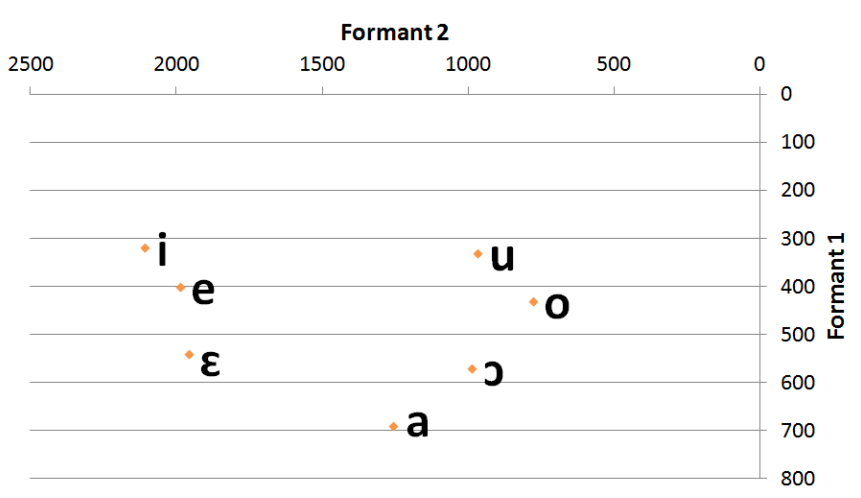

Fig. 1. Acoustic vowel chart of Isanzu

\section{Consonants}

The consonant inventory of Isanzu consists of 24 sounds that are classified in Table 1.

Table 1. Isanzu consonants

\begin{tabular}{|l|c|c|c|c|c|}
\hline manner & Bilabial & Alveolar & Palatal & Velar & Glottal \\
\hline Plosive & $\mathrm{p} \mathrm{b}$ & $\mathrm{t}$ & & $\mathrm{k} \mathrm{g}$ & \\
\hline Nasal & $\mathrm{m} \mathrm{m}$ & $\mathrm{n} \mathrm{n}$ & $\mathrm{n}$ & $\mathrm{j} \mathrm{y}$ & \\
\hline Fricative & $\mathrm{f}$ & $\mathrm{s}$ & $\int$ & $\mathrm{x}$ & $\mathrm{h}$ \\
\hline Affricate & & $\mathrm{d}$ & $\mathrm{d}$ & & \\
\hline Trill & & $\mathrm{r}$ & & & \\
\hline Approximant & & $\mathrm{l}$ & & & \\
\hline Glide & $\mathrm{w}$ & & & $\mathrm{j}$ & \\
\hline
\end{tabular}

Plosives distinguish three places of articulation: bilabial, alveolar and velar. Voiceless plosives are aspirated ( $\mathrm{t}^{\mathrm{h}} \mathrm{at}^{\mathrm{h}} \mathrm{a}$ 'father') whereas their voiced counterparts are not aspirated. In the intervocalic position /b/ becomes semi-voiced (ikolubi 'big'). /d/ alternates with the approximant $/ 1 /$ in the noun class prefix 5a (dorya/lorya 'feather'). $/ \mathrm{k} /$ is being weakened to velar fricative $/ \mathrm{x} /$ in intervocalic position (koloxa 'to vomit').

There are two sets of nasals in Isanzu: voiced and voiceless. Voiceless nasals are positional allophones of voiced nasals. The voiceless nasals appear as the outcome of the collision between homorganic nasal and a voiceless stop that results in consecutive aspiration and destopping $\mathrm{NC}>\mathrm{NCh}>\mathrm{Nh}$. From the stop, it has assimilated, the nasal inherits place of articulation and aspiration that lowers its sonority. Schematically this process can be represented in Fig. 2. 


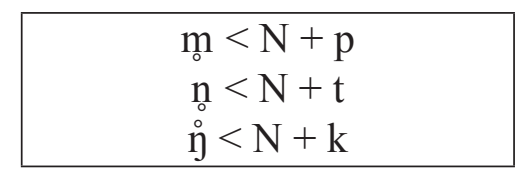

Fig. 2. Formation of voiceless nasals in Isanzu

Voiceless nasals can be found in the noun prefixes of classes $9 / 10$ and in the verb subject marker 1SG (’’aranga 'peanut' $<\mathrm{N}+$ karanga, mula 'nose' $<\mathrm{N}+$ pua, ningo 'neck' $<\mathrm{N}+$ tingo, nakire 'I wanted' $<\mathrm{n}+$ takire).

Fricatives distinguish five places of articulation: bilabial, alveolar, palatal, velar and glottal. They all are voiceless. Voiced alveolar sibilant/z/ forms a part of the affricate /dz/ and does not appear independently. The second Isanzu affricate/dz/is voiced and palatal.

Trill /r/ and approximant / $/$ are in free alternation as it is the case in many Bantu languages. However /r/ appears often in intervocalic position.

Isanzu possess two glides /w, $\mathrm{j}$ / that appear to break up VV clusters (mpwani [mpuani] 'coast', korya [koria] 'to eat').

\section{Syllable structure and sound changes}

The basic Isanzu syllable structure is CV (sa.ka.mi [CV.CV.CV] 'blood'). However, some modifications of the basic structure are possible. A syllable can be formed by only one vowel at the beginning of the word (i.ha.ka [V.CV.CV] 'forest'), by a nasal, a consonant and a vowel (nsi.e [NCV.V] 'fish'), by a consonant, a glide and a vowel (nyo.nyi [NGV.NGV] 'bird'), by only a nasal when the subsequent vowel is omitted in spoken language (m.bwa [N.CGV] 'dog').

Isanzu does not permit sequences of vowels (VV) and sequences of consonants (CC) with some exceptions. To split them when they emerge as a result of morphological changes three strategies are employed: elision, gliding and sound insertion. Elision involves vowels in tense-aspect-mood markers in verbal complexes (alema [a-a-lema] 'they cultivated', akigombya [a-ka-i-gombya] 'they agreed') and infinitive prefix (kogəpa [ko-ogəpa] 'to fear'). Gliding happens to /i, o/ turning them into /j, w/ (mwili [mo-ili] 'body', kolya [ko-lia] 'to eat'). /k/ is being inserted before reflexive -i- when it should be prevented from merger with preceding vowel (akikoa [a-a-i-koa] 'they were fighting').

\section{Practical orthography}

For the sake of further morphological analysis we adopt the following practical orthography of Isanzu. 
1. The high vowels are represented by the letters I and U.

2. The mid high vowels are represented by the letters $\mathrm{E}$ and $\mathrm{O}$.

3. The mid open vowels are represented by the symbols $\varepsilon$ and $\rho$.

4. The low open vowel is represented by the letter A.

5. Lengthening and tones are not marked in practical orthography.

6. Plosives are represented with the letters P, T, K, B, D, G. The semi-voiced /b / is represented by $\mathrm{B}$. Weakened $\mathrm{k} / \mathrm{x}$ / is represented by $\mathrm{X}$.

7. Voiced nasals are represented by the letters $M, N$, digraph $N Y / n /$ and apostrophised digraph $\mathrm{NG}^{\prime} / \mathrm{y} /$. The voiceless quality of nasals will be marked with $\mathrm{H}$ : $\mathrm{MH} / \mathrm{m} /, \mathrm{NH} / \mathrm{n} /, \mathrm{NG}^{\prime} \mathrm{H} / \stackrel{\circ}{\mathrm{y}} /$.

8. Fricatives are represented by the letters F, S, X, H and the digraph SH.

9. Affricates are represented by the letters $\mathrm{Z} / \mathrm{d} /$ and $\mathrm{J} / \mathrm{d} /$.

10. Trill and approximant are represented by the letters $\mathrm{R}$ and $\mathrm{L}$ respectively reflecting their actual variation.

11. Glides are represented with the letters W and Y.

\section{Noun class system}

Isanzu exhibits typical Bantu noun class systems with 15 classes. Noun classes are semantic domains that possess clear structural markers - prefixes and infixes - that serve for syntagmatic agreement between nouns and dependent components within noun phrases (adjectives, possessive particle $a$ 'of', verbs, demonstratives), for example: 1 i-tunhu la mogeni la-buneka

\section{CL5-CHAIR CL5-POSS GUEST CL5-FALL ${ }^{1}$}

'Guest's chair flipped over.'

In this sentence both the genitive object and the verb agree in the class with the subject while exhibiting concordial prefixes for the class $5 \mathrm{i} / \mathrm{la}$.

Isanzu concordial patterns are summarized in Table 2. Odd classes contain singular markers, even classes contain plural markers. Isanzu actively uses pre-prefix $o$ with classes 1, 3, 5a, 11, 15, 16, 17, 18 and pre-prefix $e$ with classes 2, 4, 5, 6, 7, 9, 10, 13. Functions of pre-prefixes in Bantu languages are of pragmatic nature and in the simplest cases can be compared with those of definite in European languages.

Morphological annotation is performed in accordance with the Leipziger glossing rules (available at: https:// www.eva.mpg.de/lingua/pdf/Glossing-Rules.pdf). 
Table 2. Isanzu noun class system

\begin{tabular}{|c|c|c|c|c|c|c|c|}
\hline Class & Prefix & Example & Adj. conc. & Poss. & Subject & Object & Proximal dem. \\
\hline 1 & mo & monho 'person' & mo & wa & see 5.6 & mo & oyo \\
\hline 2 & $\mathrm{a}$ & anhu 'people' & $\mathrm{a}$ & $\mathrm{a}$ & $\mathrm{a}$ & wa & awa \\
\hline 3 & mo & mote 'tree' & o & wa & o & o & owo \\
\hline 4 & me & mete 'tress' & me & $\mathrm{a}$ & $\mathrm{e}$ & $\mathrm{e}$ & eye \\
\hline 5 & $\mathrm{i}$ & ije 'egg' & $\mathrm{i}$ & la & la & la & ere \\
\hline $5 a$ & lo/ro & lodigi 'rope' & lo & la & 10 & lo & oro \\
\hline 6 & $\mathrm{ma}$ & maje 'eggs' & $\mathrm{ma}$ & $\mathrm{a}$ & $\mathrm{a}$ & $\mathrm{ma}$ & aya \\
\hline 7 & ke & 'thing' & ke & $\mathrm{ka}$ & ke & ke & eke \\
\hline 9 & $\mathrm{~N}$ & 'goat' & $\mathrm{N}$ & $\mathrm{i}$ & $\mathrm{i}$ & $\overline{\mathrm{i}}$ & eye \\
\hline 10 & $\mathrm{~N}$ & 'goats' & $\mathrm{N}$ & ya & $\mathrm{i}$ & $\mathrm{i}$ & izi \\
\hline 11 & lo & lwala 'disease' & o & wa & o & o & owo \\
\hline 13 & $\mathrm{ka}$ & kanamburi 'small goat' & $\mathrm{ka}$ & $\mathrm{ka}$ & $\mathrm{ka}$ & $\mathrm{ka}$ & aka \\
\hline 15 & ko & kong'wa 'drinking' & ko & kwa & ko & ko & oko \\
\hline 16 & po & opole 'there is' & pa & $\mathrm{pa}$ & pa & pa & apa \\
\hline 17 & ko & okole 'there is' & ko & kwa & ko & ko & oko \\
\hline 18 & mo & omole 'there is' & mo & mwa & mo & mo & omo \\
\hline
\end{tabular}

Classes 1/2 include people. Animals that are usually marked with class 9/10 prefixes may take agreement markers of class $1 / 2$, especially in narratives when they act as characters.

Classes 3/4 are reserved for plants.

Classes 5/6 include body parts, food, common objects and liquids. Class $5 \mathrm{a}$ is peculiar because of its special morphology. Instead of $i$ it uses prefix lo with the allomorph ro when preceded by the pre-prefix $o$.

Class 7 includes things, names of languages and body parts. Class 7 nouns form plural forms with the class 6, 10 prefixes (lodigi CL5a-ndigi CL10).

Classes 9/10 contain common objects, names of animals and fruits. The noun and adjectival prefixes of this classes consist of homorganic nasal that adjusts its place of articulation to that of the following sound (mburi 'goat/s' $<\mathrm{N}+$ buri [+bilabial], nharanga 'peanut/s' < N+karanga [+alveolar]).

Class 11 contains abstract nouns. Class 13 contains diminutives. Class 15 contains substantivized infinitives.

Classes 16, 17, 18 are locative classes and are employed to express spatial meanings (16 - being somewhere in an unknown place, 17 - being somewhere in a known place, 18 - being inside). 
Classes 8, 12, 14 are not attested in our data.

\section{Pronouns}

Personal and possessive pronouns, as well as corresponding subject and object markers are summarized in Table 3.

Table 3. Isanzu personal and possessive pronouns, subject and object markers

\begin{tabular}{|c|c|c|c|c|}
\hline Person & Personal pronouns & Subject markers & Object markers & Possessive roots \\
\hline $1 S G$ & one(ne) & $\mathrm{n}$ & $\mathrm{ni}$ & ane \\
\hline $2 S G$ & oe & $\mathrm{u}$ & $\mathrm{ko}$ & aks \\
\hline $3 S G$ & noanso & $\mathrm{o}$ & $\mathrm{mo}$ & akwe \\
\hline $1 P L$ & ose $(\mathrm{se})$ & $\mathrm{k}$ & $\mathrm{ke}$ & ito \\
\hline $2 P L$ & onye(nye) & $\mathrm{m}$ & wa & ayun $\varepsilon$ \\
\hline $3 P L$ & neanso & $\mathrm{a} / \mathrm{e}$ & wa & ao \\
\hline
\end{tabular}

Personal pronouns have mere emphatic than deictic function because the information about person and number is obligatory coded in verbs with subject markers. Subject and object markers are part of verb complexes and will be dealt in more details in the next section.

Possessive pronouns agree in class properties with their head nouns while taking appropriate noun class prefix, for example:

2 mo-gonda wa-ne, mo-gonda wa-ko, mo-gonda wa-kwe, etc.

CL3-FIELD CL3-MY, CL3-FIELD CL3-YOUR, CL3-FIELD CL3-HIS/HER

'my farm', 'your farm', 'his/her farm'

Morphology of proximal demonstratives (this/these) also reflects the noun class marker of the head noun. In our data we were able to find only proximal demonstratives that are summarized in Table 2. However a Bantu language Isanzu should possess at least two more sets of demonstratives.

\section{Verb morphology}

Isanzu verbs have rich morphology - prefixes, infixes and suffixes that are attached to roots. The structure of verbal phrase is represented in Fig. 3.

Negation (NEG) is the first component of a verbal phrase. It is expressed with a free staying particle shanga / singa or its first syllable sha: 
3a shanga ukikota [u-o-ki-kot-a]

NEG 2SG-FUT-REFL-BE_FULL-FV

'You will not be full [if you eat me].'

$3 b$ sha-n-e-ry-a

NEG-1SG-PRES-EAT-FV

'I don't' eat [raw meet].'

NEG-SM-TAM1-EXT1-OM-ROOT-EXT2-TAM2-FV

Fig. 3. Isanzu verb structure

Subject markers (SM) are summarized in the Table 3. It is an obligatory component of a finite verb form. However if the verb is used in its infinitive form (INF) than the place of SM is occupied by the infinitive prefix $k o$.

Slot "tense-aspect-mood marker 1" (TAM1) can be occupied by the following tense markers: $e$ - present tense, $a$-past tense, $k a$ - narrative past tense, $o$ - future, for example:

4a n-e-lem-a o-mo-gonda wa-ne kela n-siko

1SG-PRES-CULTIVATE-FV AUG-CL3-FIELD CL3-MY EVERY CL9-DAY

'I cultivate my field every day'

4 b k-a-mar-a mwaka [mo-aka]

1PL-PST-FINISH-FV CL3-YEAR

'We finished the year'

4c o-mo-kola mo-gonda we-ka-gomb-a

AUG-CL1-OWNER CL3-FIELD 3SG-PST-AGREE-FV

'[and then] the owner of the field agreed'

4d n-o-ko-tal-a

1SG-FUT-OM_2SG-BRING-FV

'I will bring you [food]'

Slot 'Extension 1' (EXT1) is reserved for the reflexive / reciprocal morpheme $i$ or its allomorph $k i$ (in intervocalic position), for example:

5 a-ng'enya akikoa [a-a-ki-ko-a]

CL2-CHILD 3PL-PST-REFL-FIGHT-FV

'Children were fighting' 
Object markers $(\mathrm{OM})$ are summarized in Tables 2 and 3. They perform anaphoric function referring to the agents that were mentioned previously or are projected as objects further.

ROOT is the bearer of lexical meaning in the verbal complex.

The slot 'Extension 2' (EXT2) can contain the following suffixes that turn the construction into a certain voice: $i$ applicative (6a), $w$ passive (6b), $z$ causative (6c), ag durative (6d), ek/ik stative (6e), for example:

6a akigombya [a-ka-i-gomb-i-a]

3PL-PST-REFL-AGREE-APPL-FV

'They agreed with [for] each other'

$6 \mathrm{~b}$ we-ka-er-w-a

3SG-PST-ASK-PASS-FV

'[and then] he was asked'

6c we-ka-poli-z-a

3SG-PST-BLOW-CAUS-FV

'[and then] he whistled'

6d leka ko-m-bol-ag-a onene

LEAVE INF-OM_1SG-KILL-DUR-FV ME

'Don't kill me'

6e e-sha-la ka mo-geni kabuneka [ka-a-bun-ek-a]

AUG-CL7-FINGER CL7_OF CL1-GUEST CL7-PST-BREAKE-STAT-FV

'Guest's finger is broken'

The slot 'tense-aspect-mood marker 2' (TAM2) can be occupied by the perfective suffix ire that combines with present and past TAM1 resulting in recent and remote past forms respectively, for example

$7 \mathrm{a}$ n-e-lem-ir-e o-mo-gonda wa-ne erereye

1SG-PRES-CULTIVATE-PFV-FV AUG-CL3-FIELD CL3-MY TODAY

'I have cultivated my field today'

$7 \mathrm{~b}$ n-a-lem-ir-e o-mo-gonda wa-ne kaletai

1SG-PST-CULTIVATE-PFV-FV AUG-CL3-FIELD CL3-MY PAST

'I cultivated my field long time ago'

Final vowel encodes mood: $a$-indicative mood, $e$ - subjunctive / optative as well as perfective, for example:

$8 \mathrm{a}$ one ko-pon-y-a i-shara mo-ndut-e

I INF-GIVE-CAUS-FV CL5-SIGN 2PL-PULL-FV 
'When I give you a sign you should pull [the rope]'

9b ni-ndel-e

OB_1SG-WAIT-FV

'You should wait for me'

\section{Conclusion}

Isanzu is a threatened Bantu lect closely related to Nilamba and Nyaturu languages. We conducted field research on Isanzu with descriptive and - to lesser extent documentary - purposes. We worked with one male consultant aged 38 who is a competent native speaker. A 207-item Swadesh list was collected and audio recorded. A questionnaire on morphological characteristics in Bantu languages was filled in and audio recorded. Two narratives were collected, transcribed and annotated. The computerized acoustic analyses performed in Praat suggests the proper transcription of vowels as /i, e, a, o, o, u/. Isanzu consonant inventory includes 24 sounds: three pairs of voiced and voiceless plosives, three pairs of voiced and voiceless nasals and one unpaired voiced palatal nasal, five voiceless fricatives, two affricates, two glides, one trill and one lateral sound. The phonemic character of these sounds remains to be an area of further research supported by more data. The noun class system of Isanzu consists of 15 classes with the following markers [nominal-pronominal]: 1 [mo-o], 2 [a-a], 3 [mo-o], 4 [me-e], 5 [i-la], 5a [lo/ro-lo/ro], 6 [ma-a], 7 [ke-ke], 9 [N-i,e], 10 [Nzi], 11 [lo-o], 13 [ka-ka], 15 [ko-ko], 16 [pa-pa], 17 [ko-ko], 18 [mo-mo]. Noun prefixes with $/ \mathrm{o} /$ are augmented with $o$, other noun prefixes are augmented with $e$. Class $5 \mathrm{a}$ is an interesting case that requires further investigation on a broader data set. Isanzu verb structure includes following slots [morphemes]: negation [sha], subject marker [n, u, o, k, m, a/e, nominal markers], tense-aspect-mood marker 1 [e 'present', a 'past', ka 'narrative past', o 'future'], extension 1 [(k)i 'reflexive/reciprocal'], object marker [ni, ko, mo, ke, wa, wa, nominal markers], root, extension 2 [i 'applicative', w 'passive', z 'causative', ag 'durative', ek/ik 'stative'], tense-aspect-mood marker 2 [ire 'perfective'], final vowel [a 'indicative', e 'subjunctive / optative / perfective']. We found a few cases of applicative and causative constructions. Further research on these structures is needed on a broader data base. Unfortunately the collected data turned to be insufficient for analyses of demonstrative sets and syntactical patterns. These areas must be added to the future research agenda. Phonetics and morphology of Isanzu reveal its conservative and regular nature. The results of this study may be useful in comparative and historical research of Bantu languages. 


\section{Acknowledgments}

We wish to cordially thank our Isanzu consultant Erasto John Linza, who provided invaluable information that serves as basis for this publication, the executives of 4 Corners Cultural Programme (4CCP) Nelson Faustin, program officer, and Julius Simon, tour guide, for their organizational and logistic support. Eventually, our appreciation goes to Reverend Fathers Joseph Martin and James Msafiri (Priests of Roman Catholic Church who belong to the Congregation of St. Augustin) for their hospitality during this research.

\section{References}

Atlasi ya lugha za Tanzania [Atlas of Tanzanian languages] (2009). Mradi wa Lugha za Tanzania [Languages of Tanzania Project]: Chuo Kikuu cha Dar es Salaam [University of Dar es Salaam]. 130.

Batibo, H.M. (2005). Language Decline and Death in Africa: Multilingual Matters LTD: Clevedon, Buffalo, Toronto, 174.

Batibo, H.M. (1990). Kidadisi cha maumbo-miundo katika lugha za Kibantu [Questionnaire on morphological characteristics in Bantu languages]. University of Dar es Salaam.

Bussmann, H. (2006). Routledge Dictionary of Language and Linguistics (translated and edited by Gregory Trauth and Kerstin Kazzazi), Routledge: London, New York. 1335.

Chelliah, S.L., de Reuse, W.J. (2011). Handbook of Descriptive Linguistic Fieldwork: Springer Netherlands. 492.

Hamisi, A. (2010). The Influence of Kiswahili in Chimalaba: A Case of Lexical and Structural Borrowing, a Dissertation for the Degree of Master of Arts (Linguistics), University of Dar es Salaam. 147.

Himmelmann, N.P. (2006). Language Documentation: What Is It And What Is It Good For? In Essentials of language documentation / ed. by J. Gippert, N.P. Himmelmann, U. Mosel, Mouton de Gruyter: Berlin, New York. 1-30.

Isanzu (2018). Available at: https://glottolog.org/resource/languoid/id/isan1243 (accessed 28 October 2018).

Isanzu: a language of Tanzania (2018). Available at: https://www.ethnologue.com/ language/isn (accessed 28 October 2018).

Kotlar, E.S. (1975). Mif i skazka Afriki [African Myths and Fairy Tales], Moscow: Nauka [Science], 244. 
Legère, K. (2002). The “Languages of Tanzania” Project: Backgrounds, Resources and Perspectives. In Africa \& Asia, 2, 163-186.

Maddieson, I. (2003). The sounds of the Bantu languages. In the Bantu languages, ed. by D. Nurse, Gérard Philippson, Routledge: London, New York. 15-39.

Masele Balla, F.Y.P. (2001). The linguistic history of Si Suumbwa, KI Sukuma and KI Nyamweezi in Bantu Zone F: A Thesis Submitted for the Degree of Doctor of Philosophy, Memorial University of Newfoundland, Department of Linguistics, 794.

Mosel, U. (2012). Morphosyntactic Analysis in the Field: A Guide to the Guides. In the Oxford Handbook of Linguistic Fieldwork, ed. by Nicholas Thieberger: Oxford University Press, 72-89.

Muzale, H.R., Rugemalira, J.M. (2008). Researching and Documenting the Languages of Tanzania. In Language Documentation \& Conservation, Vol. 2, 1 (June 2008), 68-108.

Petzel, M. (2012). The linguistic situation in Tanzania. In Moderna språk, 1, 136-144.

\title{
Фонетико-морфологический обзор языка исанзу (банту, Танзания)
}

\author{
С. Белецкий, М.П. Диямми \\ Университет Додомьл \\ Танзания, Додома, а/я 259
}

\begin{abstract}
В статье представлены результаты полевого исследования банту языка исанзу (F31B), который распространен в северной части Центральной Танзании. Цель исследования заключалась в описании фонетики и морфологии языка. Данные собирались методом двуязычной элиситации с помощьюю 207-словного списка Сводеша, анкеты, разработанной Г. Батибо для изучения морфологии и синтаксиса языков банту; кроме этого были записаны, затранскрибированы и снабжены аннотащией два устных нарратива (сказка и пересказ «истории о грушах»). Анализ данных показал, что система гласных исанзу состоит из семи гласных /i, e, a, э, о, u/, система согласных включает в себя 24 звука / $p, b, t, d, k, g, m, m, n, n, n, \eta^{\circ}, \eta, f, s, \int, x, h, d z, d z, r, l, w, j /$, также в языке представлены два контурных тона - низкий и высокий. Система именных классов исанзу включает в себя 15 классов со следующими показателями [номинальный-прономинальный]: 1 [mо-о], 2 [a-a], 3 [mo-о], 4 [me-e], 5 [i-la], 5 a [lo/ro-lo/ro], 6 [ma-a], 7 [ke-ke], 9 [N-i,e], 10 [N-zi], 11 [lo-o], 13 [ka-ka], 15 [ko-ko], 16 [pa-pa], 17 [ko-ko], 18 [moто]. Префиксы существительных, содержащие /o/, снабжаются предпрефиксом о, остальные префиксы - предпрефиксом е. Структура глагола в исанзу может быть представлена следующей иеепокой слотов [морфем]: отрицание [sha], показатель субъекта [n, u, o, $k, m$, a/е, показатели именных классов], видовременной показатель
\end{abstract}


1 [е 'настоящее время', а 'прошедшее время', kа 'повествовательное прошедшее время', о 'будущее время'], расширитель 1 [(k)i 'рефлексив/реципрок'], показатель объекта [ni, ko, то, ke, wa, wa, показатели именных классов], корень, расширение 2 [i 'аппликатив', w 'пассив', z 'каузатив', ag 'дуратив', ek/ik 'статив'], видовременной показатель 2 [іге 'перфектив'], конечная гласная [а 'индикатив', е 'оптатив / сослагательное наклонение / перфектив']. Фонетические и морфологические особенности языка исанзу позволяют судить о его консервативном характере. Результать настоящего исследования могут быть интересны специалистам, занимающимся сопоставительным изучением языков банту, а также их историей.

Ключевые слова: исанзу, банту, Танзания, полевая лингвистика, семигласная система, именные классы.

Научная спещиальность: 10.00.00 - филологические науки. 